\title{
Recommendations for Standardized Human Pedigree Nomenclature ${ }^{1}$
}

\author{
Robin L. Bennett, ${ }^{2,9}$ Kathryn A. Steinhaus, ${ }^{3}$ Stefanie B. Uhrich, ${ }^{4}$ \\ Corrine K. O'Sullivan, ${ }^{2}$ Robert G. Resta, ${ }^{5}$ Debra Lochner-Doyle, ${ }^{6}$ \\ Dorene S. Markel, ${ }^{7}$ Victoria Vincent, ${ }^{8}$ and Jan Hamanishi ${ }^{4}$
}

The construction of an accurate family pedigree is a fundamental component of a clinical genetic evaluation and of human genetic research. Previous surveys of genetic counselors and human genetic publications have demonstrated significant inconsistencies in the usage of common pedigree symbols representing situations such as pregnancy, termination of pregnancy, miscarriage, and adoption, as well as less common scenarios such as pregnancies conceived through assisted reproductive technologies. The Pedigree Standardization Task Force (PSTF) was organized through the Professional Issues Committee of the National Society of Genetic Counselors, to establish recommendations for universal standards in human pedigree nomenclature. Nomenclature was chosen based on current usage, consistency among symbols, computer compatibility, and the adaptability of symbols to reflect the rapid technical advances in human genetics. Preliminary recommendations were presented for review at three national meetings of human genetic professionals and sent to $>100$ human genetic professionals for review. On the basis of this review process, the recommendations of the PSTF for standardized human

\footnotetext{
${ }^{1}$ Reprinted with permission from the American Joumal of Human Genetics 56:745-752, 1995, The University of Chicago Press. (C) 1995 by The American Society of Human Genetics. All rights reserved.

${ }^{2}$ Division of Medical Genetics, University of Washington Medical Center, Seattle, Washington. ${ }^{3}$ Division of Human Genetics, University of California at Irvine, Orange, California.

${ }^{4}$ Obstetrics and Gynecology, University of Washington Medical Center, Seattle, Washington. ${ }^{5}$ Center for Perinatal Studies, Swedish Medical Center, Seattle, Washington.

${ }^{6}$ Genetics Services Section, Department of Health, Seattle, Washington.

${ }^{7}$ Human Genome Center, University of Michigan, Ann Arbor, Michigan.

${ }^{8}$ Division of Genetics, University of South Carolina School of Medicine, Columbia, South Carolina.

${ }^{9}$ Correspondence should be direct to Robin L. Bennett, Medical Genetics, RG-25, University of Washington Medical Center, Seattle, Washington 98195.
} 
pedigree nomenclature are presented here. By incorporating these recommendations into medical genetics professional training programs, board examinations, genetic publications, and pedigree software, the adoption of uniform pedigree nomenclature can begin. Usage of standardized pedigree nomenclature will reduce the chances for incorrect interpretation of patient and family medical and genetic information. It may also improve the quality of patient care provided by genetic professionals and facilitate communication between researchers involved with genetic family studies.

\section{INTRODUCTION}

The construction of an accurate family pedigree is fundamental to the provision of clinical genetic services and serves as an informational framework for human genetic research. Review of a family pedigree aids the clinician in diagnosis, helps establish the pattern of inheritance, and assists in identifying persons at risk. The pedigree also serves as a reference of social and biological relationships to alert the clinician to issues of blended families, adoption, deaths, pregnancy termination, and pregnancies conceived by assisted reproductive technologies. Correct interpretation of family pedigrees is essential for human genetic research and is particularly challenging when reviewing pedigrees diagrammed within professional publications or when research teams collaborate to study large families. Pedigree analysis also facilitates the identification of disorders where genetic mechanisms such as anticipation, mitochondrial inheritance, $\mathrm{X}$-linked or dominant homozygous lethality, and differential age at onset, based on the sex of the transmitting individual, are factors.

Although one might assume that pedigree nomenclature is used in a universal fashion, we have demonstrated wide variation among genetics professionals, both in clinical practice and in professional publications. A survey of members of the National Society of Genetic Counselors (NSGC) showed discrepancies even in common symbols used to record a genetic family history (i.e., pregnancy, miscarriage, abortion, termination of pregnancy, adoption) (Bennett et al., 1993). No consensus was noted in recording situations representing assisted reproductive technologies (i.e., artificial insemination by donor semen, donor ovum, surrogate motherhood). A review of 24 standard medical genetic textbooks and publications in ten current human genetic journals further demonstrated wide variation in pedigree construction (Steinhaus et al., in press). Historical studies have also shown a lack of consistency in pedigree symbols throughout the twentieth century (Resta, 1993). 
Standardization of pedigree nomenclature is important, much as it was useful to develop universal cytogenetic nomenclature (Paris Conference, 1971). The Pedigree Standardization Task Force (PSTF) was established through the Professional Issues Committee of the NSGC to address this issue and to make recommendations for standardized human pedigree nomenclature. The recommendations of the PSTF are presented here.

\section{MATERIAL AND METHODS}

A draft of proposed pedigree nomenclature was developed by reviewing symbols and abbreviations used by genetic counselors in clinical practice, on the basis of 437 questionnaire responses by NSGC members (Bennett et al., 1993). Pedigree nomenclature in professional human genetic publications, including current journal articles and standard human genetic textbooks, was also reviewed (Steinhaus et al., in press). In addition to frequent usage, consistency among symbols, computer compatibility, and ability to adapt to the rapid changes in human genetics were considered.

A peer review of the proposed pedigree nomenclature was conducted. A first draft of proposed symbols was circulated to a liaison committee that included representatives from the NSGC, the American Board of Medical Genetics, the American Society of Human Genetics (ASHG), the American Board of Genetic Counseling, the Washington State Department of Health, editors of various genetic publications, the Education Committee of the Council of Regional Genetics Networks (CORN), the Adoption Subcommittee of CORN, the Alliance of Genetic Support Groups, and the International Society of Nurses in Genetics. The resulting recommendations were presented in poster format at the 1993 annual education conferences of the NSGC in Atlanta and the ASHG in New Orleans, allowing participants at these meetings the opportunity to provide both verbal and written response to the PSTF. After incorporation of reviewer commentary, a revision was presented as a poster at the 1994 joint meeting of the March of Dimes Education Conference and the American College of Medical Genetics (ACMG) in Kissimmee, Florida, again allowing an opportunity for comment by practicing genetic professionals. A third revision of the pedigree nomenclature was sent, in April 1994, to $\sim 120$ genetic professionals, including journal editors, chairs of the major professional genetic societies and organizations (including the newly formed ACMG), directors of genetic counseling training programs, authors of standard human genetic textbooks, and other leaders in the field of human genetics. The proposed nomenclature was field-tested by small focus groups, including members of the Education Committees of the Pacific Northwest Regional Genetics Group and 
the Pacific Southwest Regional Genetics Group, and master's-level genetic counseling students at the University of Wisconsin. A fourth revision was distributed in July 1994 to $\sim 70$ genetic professionals from the original list of 120 . Minor revisions were made in this fourth draft, which was then submitted to, and approved by, the PSTF liaison members.

\section{RESULTS}

The NSGC PSTF's recommendations for symbolization of a genetic family history are outlined in Figs. 1-5. These recommendations apply both to unpublished clinical pedigrees and to research publication, once identifying information (i.e., birthdates, names) has been removed. The Appendix

\begin{tabular}{|c|c|c|c|c|}
\hline \multicolumn{5}{|c|}{$\begin{array}{l}\text { Instructions: } \\
\text { - Key should contain all information relevant to interpretation of pedigree (e.g., define shading) } \\
\text { - For clinical (non-published) pedigrees, include: } \\
\text { a) family names/initials, when appropriate } \\
\text { b) name and title of person recording pedigree } \\
\text { c) historian (person relaying family history information) } \\
\text { d) dare of intake/update } \\
\text { - Recommended order of information placed below symbol (below to lower right, if necessary): } \\
\text { a) age/date of birth or age at death } \\
\text { b) evaluation (see Figure } 5 \text { ) } \\
\text { c) pedigree number (e.g., }[-1,1-2,1-3 \text { ) }\end{array}$} \\
\hline & Male & Female & $\begin{array}{c}\text { Sex } \\
\text { Unknown }\end{array}$ & Comments \\
\hline 1. Individual & & & & Assign gender by phenotype. \\
\hline \multirow[t]{2}{*}{ 2. Affected individual } & & & & $\begin{array}{l}\text { Key/legend used to define shading or other fill } \\
\text { (e.g., hatches, dors, erc.). }\end{array}$ \\
\hline & & & & $\begin{array}{l}\text { With } \geq 2 \text { conditions, the individual's symbol } \\
\text { should be partitioned accordingly, each segment } \\
\text { shaded with a different fill and defined in legend. }\end{array}$ \\
\hline $\begin{array}{l}\text { 3. Multiple individuals, } \\
\text { number known }\end{array}$ & 5 & & & $\begin{array}{l}\text { Number of siblings writcen inside symbol. } \\
\text { (Affected individuals should not be grouped.) }\end{array}$ \\
\hline $\begin{array}{l}\text { 4. Multiple individuals, } \\
\text { number unknown }\end{array}$ & & & & "n" used in place of "?" mark. \\
\hline 5a. Deceased individual & & & & $\begin{array}{l}\text { Use of cross }(+) \text { may be confused with symbol } \\
\text { for evaluated positive }(+) \text {. If known, write "d." } \\
\text { with age at death below symbol. }\end{array}$ \\
\hline 56. Stillbirth (SB) & & & & Bith of a dead child with gestational age noted. \\
\hline 6. Pregnancy $(\mathrm{P})$ & LMP: 71194 & & & $\begin{array}{l}\text { Gestational age and karyotype (if known) } \\
\text { below symbol. Lighr shading can be used } \\
\text { for affected and defined in keylegend. }\end{array}$ \\
\hline 7a. Proband & & & & $\begin{array}{l}\text { First affected family member coming to } \\
\text { medical attention. }\end{array}$ \\
\hline 7b. Consultand & & & Individua & (s) seeking genetic counseling/testing. \\
\hline
\end{tabular}

Fig. 1. Common pedigree symbols, definitions and abbreviations. 


\begin{tabular}{|c|c|c|c|c|}
\hline \multicolumn{5}{|c|}{$\begin{array}{l}\text { Instructions: } \\
\text { - Symbols are smaller than standard ones and individual's line is shorrer. (Even if sex is known, triangles } \\
\text { are preferred to a small square/circle; symbol may be raistaken for symbols } 1,2 \text {, and } 5 \mathrm{a} / 5 \mathrm{~b} \text { of Figure } 1 \text {, } \\
\text { particularly on hand drawn pedigrees.) } \\
\text { - If gender and gestational age known, write below symbol in that order. }\end{array}$} \\
\hline & Male & Female & $\begin{array}{c}\text { Sex } \\
\text { Unknown }\end{array}$ & Comments \\
\hline $\begin{array}{l}\text { 1. Spontaneous abortion } \\
\text { (SAB) }\end{array}$ & & $\widehat{\text { female }}$ & $\bigotimes_{E C T}$ & If ecropic pregnancy, write ECT below symbol. \\
\hline 2. Affected $\mathrm{SAB}$ & & & & $\begin{array}{l}\text { If gestational age known, write below symbol } \\
\text { Key/legend used to define shading. }\end{array}$ \\
\hline $\begin{array}{l}\text { 3. Termination of } \\
\text { pregnancy (TOP) }\end{array}$ & $4 x$ & $\underset{\text { female }}{X}$ & $\beta$ & $\begin{array}{l}\text { Orher abbreviations (e.g., TAB, VTOP, Ab) } \\
\text { nor used for sake of consistency. }\end{array}$ \\
\hline 4. Affected TOP & & & & Key/legend used to define shading. \\
\hline
\end{tabular}

Fig. 2. Pedigree symbols and abbreviations for pregnancies not carried to term.

and Fig. 1A provide an example of a hypothetical clinical history and a pedigree utilizing the recommended pedigree nomenclature, to illustrate the relationship of symbols to each other and the placement of information on the pedigree.

\section{DISCUSSION}

The pedigree is the symbolic language of clinical genetic services and of human genetic research. In this age of increasing information exchange, standardization of the language of the human pedigree is essential for clear communication among medical professionals and genetic researchers. As with the development of cytogenetic nomenclature, the development of uniform pedigree nomenclature is an evolving process. The utility and the effectiveness of the proposed pedigree nomenclature need to be evaluated in the future. Plans for assessment include review of genetic publications, in a few years time, to determine whether the symbols are indeed being used by the authors. In addition, a sample of members of the professional genetics organizations can be surveyed about the value of the pedigree nomenclature guidelines in their clinical practice and research.

There are several methods for incorporating standardized pedigree nomenclature into practice. Teaching uniform pedigree symbols in human genetic professional training programs, in medical and nursing schools, and to allied health professionals, as well as including standard pedigree nomenclature in board examinations, will encourage the next generation of health-care providers to integrate this nomenclature into their routine. If genetic diagnostic labs require standardized pedigrees on their intake and 


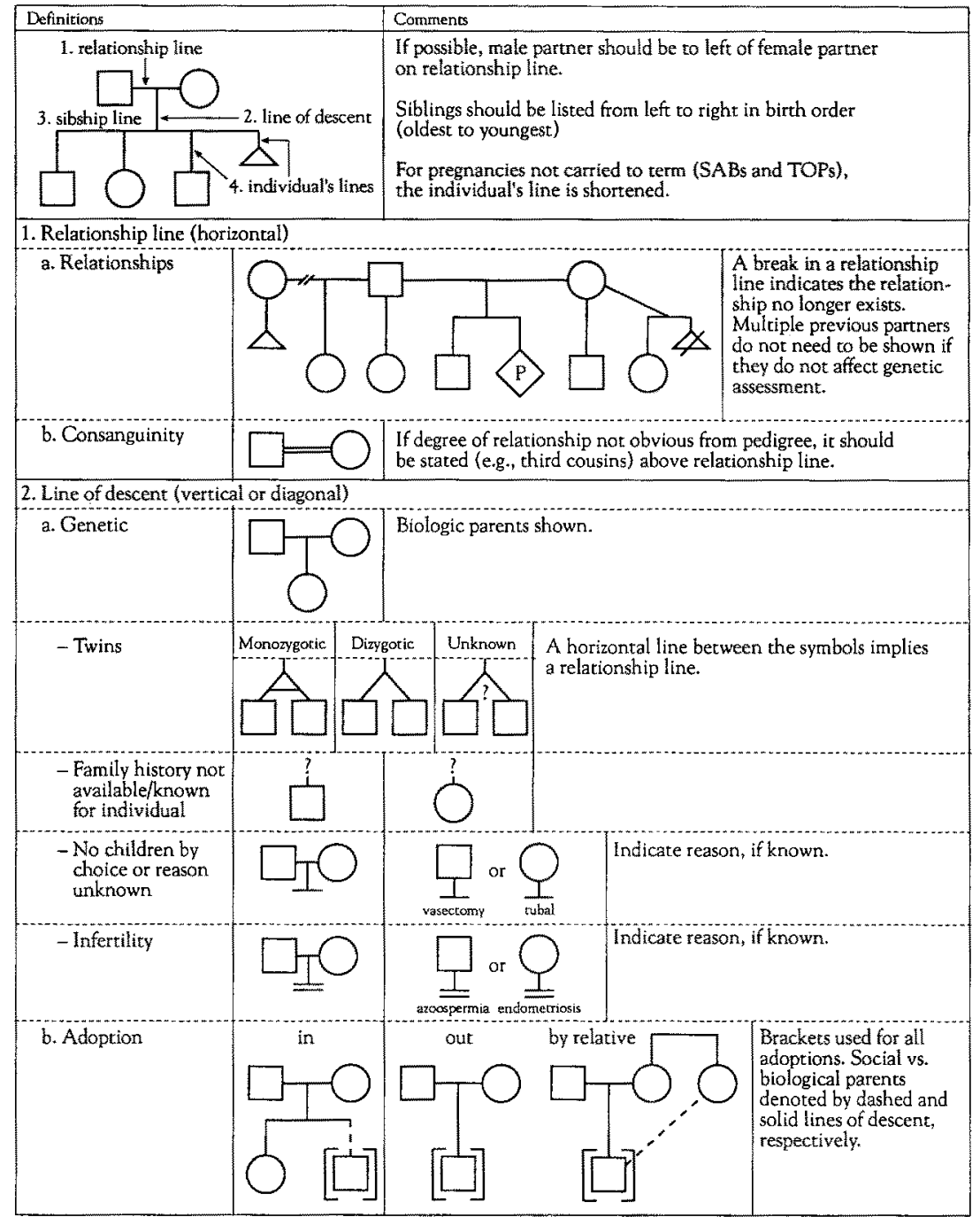

Fig. 3. Pedigree line definitions.

reporting forms, this may improve communication between the laboratory and referring health professional. Computer programs that incorporate uniform symbols for recording family histories would be useful. Editors of genetic publications should be encouraged to include standardized pedigree nomenclature in their journals' information for contributors and in textbooks. 


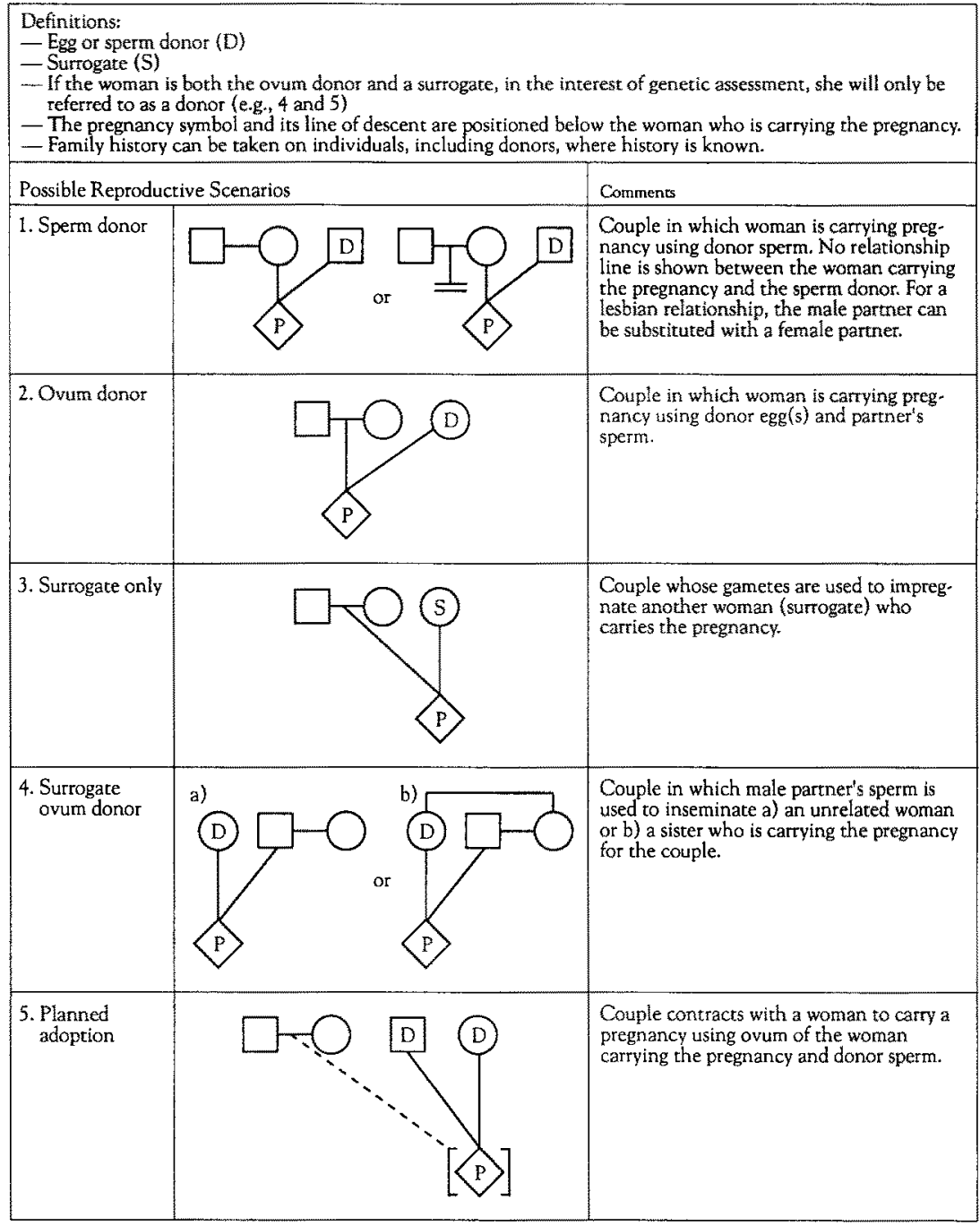

Fig. 4. Assisted reproductive technologies (ARTs) symbols and definitions.

Of equal importance to the development of standardized pedigree symbolization is the development of professional guidelines regarding ethical issues in recording a clinical genetic family history, as well as in publication of pedigrees. For instance, in Fig. 5, example 3, the suggested symbol for an asymptomatic/presymptomatic carrier (e.g., a person with no 


\begin{tabular}{|c|c|c|c|}
\hline $\begin{array}{l}\text { Instructions: } \\
\text { - Evaluation (E) is used to } \\
\text { a. E is to be defined in key } \\
\text { b. If more than one evalu } \\
\text { side by side or below ea } \\
\text { c. Test results should be p } \\
\text { d. If results of exam/famil } \\
\text { - Documented evaluation ( } \\
\text { a. Asterisk is placed next } \\
\text { b. Use only if examined/e } \\
\text { personally reviewed an } \\
\text { - A symbol is shaded only } \\
\text { - For linkage studies, haplo } \\
\text { be on left and appropriate } \\
\text { - Reperitive sequences, trin } \\
\text { placed in parentheses. } \\
\text { - If mutation known, ident } \\
\text { - Recommended order of in } \\
\text { 1) age/date of birth or age } \\
\text { 2) evaluation information } \\
\text { 3) pedigree number (e.g., }\end{array}$ & $\begin{array}{l}\text { resent } \\
\text { gend. } \\
\text { on, use s } \\
\text { other d } \\
\text { in paren } \\
\text { cudy/test } \\
\text { lower ris } \\
\text { uated b } \\
\text { erified. } \\
\text { on an in } \\
\text { hinforn } \\
\text { highligh } \\
\text { leotides } \\
\text { and plas } \\
\text { mation: } \\
\text { death } \\
\text {, I-2, I-3 }\end{array}$ & $\begin{array}{l}\text { inical and/or test information on the pedigree } \\
\text { ibscript }\left(E_{1}, E_{2}, E_{3}\right) \text { and define in key. May be } \\
\text { pending on available space. } \\
\text { heses or defined in key/legend. } \\
\text { ng not documented or unavailable, may use a } \\
\text { ht edge of symbol. } \\
\text { you or your research/clinical team or if the o } \\
\text { ividual is clinically sympromatic. } \\
\text { ation is writren below the individual. The ha } \\
\text { ted. } \\
\text { and expansion numbers are written with affec } \\
\text { e in parentheses. }\end{array}$ & $\begin{array}{l}\text { written } \\
\text { question matk (c.g., E?). } \\
\text { Itside evaluation has been } \\
\text { ed allele first and }\end{array}$ \\
\hline Definition & Symibol & Scenario & Example \\
\hline $\begin{array}{l}\text { 1. Documented } \\
\text { evaluation ( }\end{array}$ & & $\begin{array}{l}\text { Woman with normal physical exam and } \\
\text { negative fragile } X \text { chromosome study (nor- } \\
\text { mal phenotype and negative test result). }\end{array}$ & \\
\hline $\begin{array}{l}\text { 2. Obligate carrier (will not } \\
\text { manifest disease). }\end{array}$ & & $\begin{array}{l}\text { Woman with normal physical exam and } \\
\text { premutation for fragile } X \text { (normal pheno. } \\
\text { type and positive test result). }\end{array}$ & $(\overbrace{E+(100 n / 35 n)}$ \\
\hline $\begin{array}{l}\text { 3. Asymptomatic/presymp- } \\
\text { tomatic carrier (clinically } \\
\text { unaffected at this time } \\
\text { bur could later exhibit } \\
\text { symptoms) }\end{array}$ & & $\begin{array}{l}\text { Man age } 25 \text { with nornal physical exam } \\
\text { and positive DNA test for Huntington } \\
\text { disease (symbol filled in if/when symp- } \\
\text { toms develop). }\end{array}$ & $E+(4$ \\
\hline 4. Uninformative study (u) & Eu & $\begin{array}{l}\text { Man age } 25 \text { with normal physical exam } \\
\text { and uninformative DNA test for Hunting. } \\
\text { ton disease }\left(E_{1}\right) \text { and negative brain MRI } \\
\text { study }\left(E_{2}\right) \text {. }\end{array}$ & 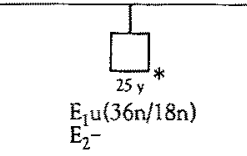 \\
\hline $\begin{array}{l}\text { 5. Affected individual with } \\
\text { positive evaluation }(\mathrm{E}+)\end{array}$ & $E+$ & $\begin{array}{l}\text { Individual with cystic fibrosis and posi- } \\
\text { tive mutation study, although only one } \\
\text { mutation has currently been identified. }\end{array}$ & $E+(\Delta F 508) \underbrace{\bullet}_{E+(\Delta F 508 / 4)}$ \\
\hline & & $\begin{array}{l}18 \text { week male fetus with abnormalities } \\
\text { on ultrasound and a trisomy } 18 \text { karyotype. }\end{array}$ & $\begin{array}{c}\text { Ed } \\
E+(\operatorname{tri} 18)\end{array}$ \\
\hline
\end{tabular}

Fig. 5. Pedigree symbolization of genetic evaluation/testing information.

clinical symptoms of Huntington disease who carries the mutation) is shown, but it could be argued that, for confidentiality reasons, presymptomatic test results should not be recorded on the pedigree or even in the patient chart. Likewise, large pedigrees are published in research papers 


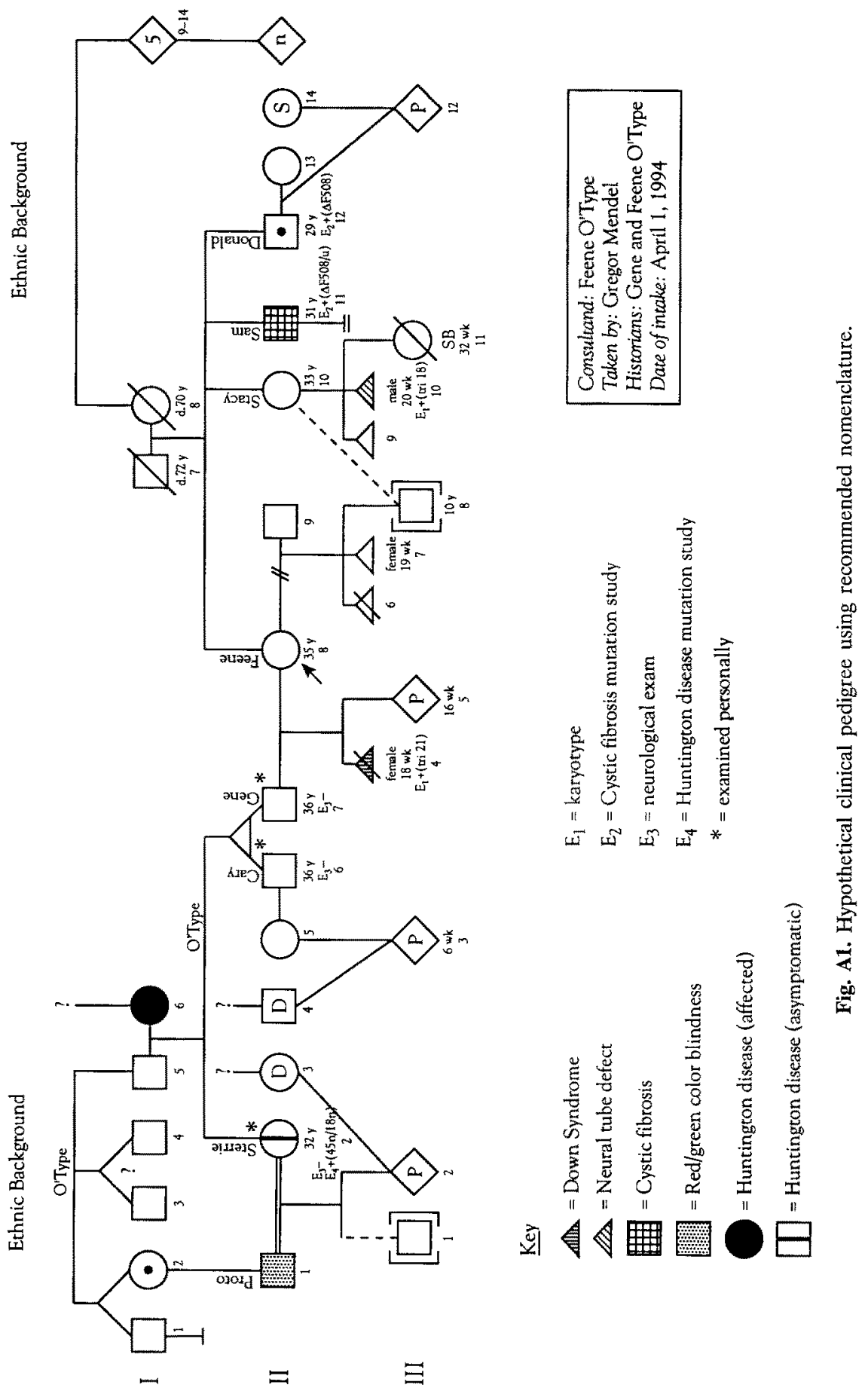


where an individual could be identified from the family structure, genetic condition, and the names of the researchers, yet consent for publication may not have been obtained from each person who is symbolized on the pedigree.

The development of ethical guidelines about the type of information recorded on a pedigree should be considered. For example, information that is commonly recorded on a pedigree (e.g., same-sex relationships, suicide, alcoholism, HIV status, marital status, pregnancy terminations) may or may not be helpful in making a clinical diagnosis and genetic-risk assessment; however, this type of information, if released to a third party (e.g., insurer, employer), may be used in a discriminatory fashion. The kind of information documented on a pedigree also raises issues of protection of privacy when a family pedigree is exchanged between health professionals evaluating different members of an extended family. The pedigree may contain information not privy to the other relatives (e.g., nonpaternity, pregnancy terminations, affected status, pregnancies conceived by assisted reproductive technologies, etc.). Researchers and clinicians need to weigh carefully patient confidentiality against clinical and genetic relevance when deciding what information to include on a pedigree.

The professional genetics community should continue to explore the many ethical and legal dilemmas surrounding the clinical and research use of the family pedigree, to assure the protection of confidentiality of our patients and subjects. A conference sponsored by the American Association for the Advancement of Science (AAAS)-American Bar Association (ABA) National Conference of Lawyers and Scientists, and the AAAS Committee on Scientific Freedom and Responsibility met to address some of the issues involved in pedigree research but did not arrive at a consensus (Frankel and Teich, 1993). The Council of Biological Editors has also raised the issue of protection of privacy for individuals in published pedigrees (Glass et al., 1994). Problems such as misuse of published information, leading to job loss and problems of obtaining life insurance, were addressed. Solutions such as altering or omitting symbols to disguise the family and obtaining consent from each person in a published pedigree were discussed, but no agreement was reached. The professional human genetics societies may wish to consider the development of policy statements to address the issues of confidentiality for subjects in clinical and research pedigrees.

This document is the result of the thoughtful input from many professionals in the genetics community. It is impossible to develop uniform pedigree nomenclature without creating controversy. The problem is succinctly stated by Frances Galton $(1889$, p. 249$)$, who noted: "There are 
many methods of drawing pedigrees and describing kinship, but for my own purposes I still prefer those that I designed myself." The proposed recommendations of the PSTF are made as a starting point in the process of adopting uniform pedigree nomenclature. By beginning to use uniform guidelines for pedigree construction in professional publication and clinical and research practice, it is possible to reduce the chances for incorrect interpretation of patient and family medical and genetic information. It may also improve the quality of patient care provided by genetic professionals, as well as facilitate communication between researchers involved with genetic family studies.

\section{ACKNOWLEDGMENTS}

This work was supported by grants from the National Society of Genetic Counselors; the Washington State Department of Health; Maternal/Infant Health and Genetics, the Pacific Northwest Regional Genetics Group Project MCJ-411002-10, and the University of Washington Division of Medical Genetics and Department of Obstetrics and Gynecology. The pedigree symbols in the figures were formatted using Aldus PageMaker. We are grateful to the many people who have commented on this project and for the support from Ann Happ-Boldt, Wendy Uhlmann, and Vickie Venne.

\section{APPENDIX. FICTITIOUS GENETIC FAMILY HISTORY AND PEDIGREE, USING RECOMMENDED PEDIGREE NOMENCLATURE}

\section{Clinical Scenario}

The consultant, Mrs. Feene O'Type, age 35 years, and her 36-year-old husband, Gene O'Type, are referred to you for genetic counseling regarding advanced maternal age, since Mrs. O'Type is 16 wk into her pregnancy. Mrs. O'Type had one prior pregnancy, an elective termination (TOP) at $18 \mathrm{wk}$, of a female fetus with trisomy 21.

Mrs. O'Type and Her Side of the Family

- Mrs. O'Type had three prior pregnancies with an ex-husband, the first a TOP, the second a spontaneous abortion (SAB) of a female fetus at 
19 wk gestation, and the third a healthy 10 -year-old son who was subsequently adopted by her 33-year-old sister, Stacy.

- Stacy had three pregnancies, two SABs (the second a male fetus at 20 wk with a neural tube defect and a karyotype of trisomy 18), and a stillborn female at $32 \mathrm{wk}$.

- Mrs. O’Type has a 31-year-old brother, Sam, who is affected with cystic fibrosis (CF) and is infertile.

- Her youngest brother, Donald, age 29 years, is healthy and married. By means of gametes from Donald and his wife, an unrelated surrogate mother has been successfully impregnated.

- Mrs. O'Type's father died at age 72 years and her mother at age 70 years, both from "natural causes." Mrs. O'Type's mother had five healthy full sibs, who themselves had many healthy children.

\section{Mr. O'Type and His Side of the Family}

- Mr. O'Type has two siblings, an MZ twin brother, Cary, whose wife is 6 wk pregnant by donor insemination (donor's history unknown), and a 32-year-old sister, Sterrie.

- Sterrie is married to Proto, her first cousin (Sterrie's father's sister's son), who has red/green color blindness. She is carrying a pregnancy conceived from Proto's sperm and ovum from an unknown donor. Sterrie and Proto also have an adopted son.

- The family history of Sterrie's mother, who has Huntington disease (HD), is unknown.

- Mr. Gene O'Type's father has a set of twin brothers, zygosity unknown, and another brother and a sister (Proto's mother) who are also twins.

\section{Later You Obtain the Following Information}

- Feene O'Type's brother, Sam, with CF, has one $\Delta \mathrm{F}$ allele and one allele that cannot be identified.

- Donald carries the $\Delta \mathrm{F}$ allele.

- Gene O'Type and his twin brother show no clinical signs of $\mathrm{HD}$, on examination by the neurologist in your clinic. Gene would like DNA testing, but Cary is not interested.

- Sterrie has a normal neurological exam (for symptoms of HD) in your clinic, but her DNA testing shows she has a CAG expansion of 45 and 18 repeats. 


\section{REFERENCES}

Bennett RL, Steinhaus KA, Uhrich SB, O'Sullivan C (1993) The need for developing standardized family pedigree nomenclature. $J$ Genet Couns 2:261-273.

Frankel MS, Teich AH (1993) Ethical and legal issues in pedigree research. Report on a conference sponsored by the AAAS Committee on Scientific Freedom and Responsibility and the AAAS-ABA National Conference of Lawyers and Scientists. American Association for the Advancement of Science, Washington, DC.

Galton F (1889) Natural Inheritance. London: MacMillan.

Glass R, Motulsky AG, Juengst E, Squires B (1994) Ethics and the publication of clinical genetics. CBE Views 17(5): 70-71.

Paris Conference (1971) Supplement (1975): Standardization in human cytogenetics. Birth Defects Original Article Series 11. Vol 9. New York: National Foundation.

Resta RG (1993) The crane's foot: the rise of the pedigree in human genetics. J Genet Couns 2:235-260.

Steinhaus KA, Bennett RL, Uhrich SB, Resta RG, Doyle DL, Markel DS, Vincent VA. Inconsistencies in pedigree nomenclature in human genetics publications: a need for standardization. Am I Med Genet (in press). 